\title{
Blood Brothers in Despair: Greek Brigands, Albanian Rebels and the Greek-Ottoman Frontier,
} 1829-1831

Frères de sang au désespoir : brigands grecs, rebelles albanais et la frontière gréco-ottomane, 1829-1831

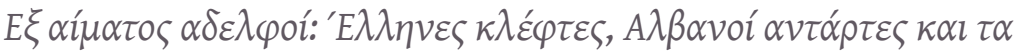

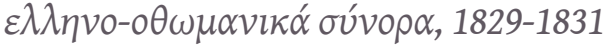

\section{Basil C. Gounaris}

\section{(2) OpenEdition}

\section{Journals}

Electronic version

URL: https://journals.openedition.org/ceb/11433

DOI: $10.4000 / c e b .11433$

ISSN: 2261-4184

\section{Publisher}

INALCO

Printed version

ISBN: 978-2-85831-294-8

ISSN: 0290-7402

\section{Electronic reference}

Basil C. Gounaris, "Blood Brothers in Despair: Greek Brigands, Albanian Rebels and the Greek-Ottoman Frontier, 1829-1831", Cahiers balkaniques [Online], 45 | 2018, Online since 14 December 2018, connection on 06 July 2021. URL: http://journals.openedition.org/ceb/11433 ; DOI: https://doi.org/ 10.4000/ceb. 11433

This text was automatically generated on 6 July 2021.

\section{cc) (5)}

Cahiers balkaniques est mis à disposition selon les termes de la Licence Creative Commons Attribution - Pas d'Utilisation Commerciale 4.0 International. 


\title{
Blood Brothers in Despair: Greek Brigands, Albanian Rebels and the Greek-Ottoman Frontier, 1829-1831
}

\author{
Frères de sang au désespoir : brigands grecs, rebelles albanais et la frontière \\ gréco-ottomane, 1829-1831

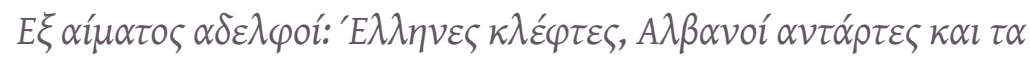

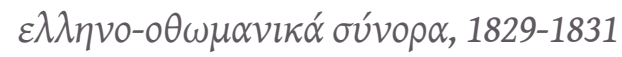

Basil C. Gounaris

1 By the time the Greek War of Independence had reached its final stages in 1829, negotiations for the demarcation of the new state's borders had not yet been completed. A long-drawn-out diplomatic process carried on until 1832. During a period of almost three years there was neither a formal frontier line nor de jure independence for Greece, while the Ottoman Empire was engaged in fierce domestic wars with Albanians, Bosnians and Egyptians. ${ }^{1}$ The future of comparatively extensive provinces in Sterea Hellas (the Hellenic terra firma, also known in Greek as Roumeli) ${ }^{2}$ was debated, and on paper changed ownership three times in a space of two years. ${ }^{3}$ Half of the provinces that would eventually be included in the Greek state constituted a disputed borderland. Following a disastrous decade of war, local Greek and Albanian military élites found themselves in an awkward position. The ceasefire of September 1829 and the indiscernible yet impending frontiers were restricting their options and threatened their welfare in unexpected ways. They could not and did not stay idle. They exploited tradition and modernity, most of all their rich experience in political manoeuvring, in order to bargain for a better position for themselves in the coming new era. Their choices varied, yet their method was uniform. It was the only method they knew in pursuing their cause: to bargain tough before compromising, even if the given choice involved extensive civil strife. Their adversaries, a crumbling Empire and the soon-to-be Greek nation-state, were unpredictable in their responses. Closely monitored by the European powers, the Grand Vizier Mehmed Reşid and Governor 
Ioannis Kapodistrias had to show determination and improvisation, in order to gain the necessary prestige and win back the disputed territories. The purpose of this paper is to analyse and explain the politics of survival adopted by the military élites of the new frontiers, the interaction between the two centres, the Sublime Porte and Kapodistrias, and their respective borderlands, in the absence of concrete territories and in the presence of a trans-ethnic network of delicate Greek-Albanian relations.

\section{During the War of Independence: Albanians between Greeks and Turks}

2 The last battle of the War of Independence was fought on September 12, 1829 at Petra in Boeotia, close to the battlefield of Aliartos, where the Thebans had defeated the Spartans in 395 BC. The Greek revolutionary forces were headed by Field Marshal Dimitrios Ypsilantis, a former officer of the Imperial Russian Army, and brother of Prince Alexandros Ypsilantis. The latter had kicked off Greek revolutionary activities in February 1821, when he crossed the Prut River into the Ottoman controlled Danubian Principalities and issued a proclamation urging Hellenes to rise for "faith and country." By the time of Dimitrios' victory in 1829, Alexander had already died in poverty in Vienna (Jan. 1828), having spent seven years in close confinement by the Austrians. The youngest brother completed the task the eldest had set, and made his martyrdom worthwhile. The symbolism was great and outlived the details of the Petra battle. ${ }^{4}$ Few Greeks today know who were in charge of the defeated Ottoman forces and why they surrendered. Had they known, they would have acknowledged an additional symbolism, or perhaps a historical irony.

One of the two compromised Ottoman leaders, on the head of a few hundreds Albanians, was a Tosk in his early twenties, A[r]slan Bey Puzzi, also called Aslan Mühürdar, i.e. the seal-keeper. It seems he was the son of Ali Pasha's trusted seal-keeper Mehmed Bey Karamurat, who allegedly had inherited a quarter of his master's legendary treasure. ${ }^{5}$ After the battle of Petra, Aslan Bey and his co-leader Osman Agha, were quick to strike a deal with Ypsilantis, allowing them a safe passage to the north in exchange of some fortified positions which would secure Greek control up to Spercheios River. This compromise was crucial for diplomacy. The Greeks were anxious to secure a firm grip on Roumeli, yet unaware that nine days before, in Adrianople, the Russians had already imposed on the defeated Ottomans the Volos-Amvrakikos line as the future frontier of Greece. ${ }^{6}$ The irony was that in the early stages of the Greek Revolution, in the summer of 1821, Dimitrios Ypsilantis had invited the "brave Tosks" to side with the Greeks, then at war with Ali Pasha. ${ }^{7}$ Eight years on, the Tosks were still on the side of the Ottomans, defending the interests of the Ottoman government up to the very last battle. Apparently, the Greek appeal had been in vain.

This narrative is somehow misleading, for some interesting episodes are missing. The Tosks are one of the two Albanian population groups, which, at the time, resided south of the Scubi River, as far south as the Gulf of Amvrakikos. Compared to their northern neighbours, the warlike, arrogant, and rough Suni Muslim Geghs, Tosks, especially the lowland Cham tribes, with their fair complexion, were considered by nineteenth-century observers as more friendly and hospitable, yet poor and filthy. They were the followers of the tolerant to the Christian faith Bektashi order and were in close social and economic contact with the Greeks of Southern Albania and Epirus. 
Greeks thought of the Geghs, or "Skodrins," as a different tribe with a distinctive ethos. ${ }^{8}$ British diplomats classified them as a different nation, whatever this term meant in their early nineteenth-century vocabulary. ${ }^{9}$ This did not imply that Tosks were less involved in eighteenth-century raids against their Christian neighbours, especially against the warlike and hard to subdue Souliots. However, within the court and the military apparatus of Ali Pasha Tepelenli, the notorious semi-independent Albanian ruler, a trilingual élite, of Tosk and Greek warlords, armatoles, pass-keepers, and army commanders, came into close contact. Bonds of trust and blood were formed between them but should not be overestimated. As the war the Porte had launched against Ali and the Greek insurgents overlapped, for a brief period of time, in 1820-1821 Tosk and Greek interests converged. The Souliots joined first on the side of their former pursuer to regain their homeland. It was in this context that Dimitrios Ypsilantis encouraged the Tosks to fight together with the Greeks for their freedom against their "tyrant", the Sultan, and flattered them as descendents or "our ancestors" (i.e. the ancient Greeks), not related to the "pusillanimous Orientals and the infidel Skythians". This coalition culminated into a joint and almost successful operation against numerous Ottoman forces holding the town of Arta by the armatoles of Aetolia and Akarnania, the Souliots and some Tosk leaders. The venture was short-lived. Before the end of 1821, it became clear to the Tosks that the Greeks were fighting for a different cause, for another faith, not for Ali Pasha but against Islam. Apparently, they had been deceived and had disgraced themselves for an unjust reason. They reinstated their allegiance to the Sultan, yet they treasured their military word of honour and took care that the Souliots drift away smoothly and safely. ${ }^{10}$ A few months earlier, in September, General Theodoros Kolokotronis had also taken all the necessary precautions to secure a safe passage out of the Peloponnese for the Albanians of Tripolitsa, on the eve of the notorious massacre he carried out. ${ }^{11}$ The following year (1822) the same Greek officer tried to win over the Albanians by exploiting the legacy of Ali Pasha, but his letter was intercepted; not that his appeal stood any chance. ${ }^{12}$ By that time, the ruler of Epirus was dead, while operations against the Greeks, which included extensive plundering and slave trading, kept Tosks and Geghs alike extremely busy and content. On their head were some of Ali's best warlords and adamant supporters, who had turned into a true menace for the insurgent Greeks. Yet, incidents of personal contact and mutual assistance between Greeks and Albanians did not cease throughout the war.

Albanian active participation did not eliminate Ottoman mistrust, which went back to at least the late eighteenth century, long before Ali had built his semi-autonomous state. ${ }^{13}$ The Tosks in particular, the backbone of Ali's state mechanism, were suspected of disloyalty to the Sultan and luck of true religious fervour for Islam. Even the famous general Omer Vrioni, with a distinguished record in the battles against the British in Egypt (1807), was not an exception. He had served Ali, but cut himself a deal with the Porte and abandoned his master just in time to fight against him. In Ottoman reports, it was regularly repeated that the Albanians' motive was exclusively money. They were not fighting for their Sultan. They were true mercenaries and, in need of capital, they would sell their services to the highest bidder, even if he was not a Muslim. Numerous instances of refusing to join in the war against infidels without advance payment and various incriminating letters intercepted from time to time that testified to their contacts with the Greek revolutionary captains proved their perfidious nature. Mehmed Reşid Pasha, also known as Kütahı, then commander-in-chief (serasker) of the Ottoman forces that led the two sieges of Missolonghi was perhaps their most severe 
critic. Of Georgian origin and a faithful slave of the Porte since childhood (kapikulu), he was unable to comprehend the Albanians' predilection to barter. Rumours run that he had been deliberately deceived by Omer Vrioni in 1822 when the latter, contrary to his view, tried to take Missolonghi by negotiations instead of an assault. Meanwhile the Greeks were reinforced and had been made aware of his plans. ${ }^{14}$

6 By the time Aslan Bey and Osman Agha faced Ypsilantis at Petra, in September 1829, Mehmed Reşid Pasha had accumulated many additional reasons to be angry with the Albanians. The tide was clearly against the Ottoman Empire since 1827. In April 1827, Kapodistrias was instated as the governor of Greece; in July, European intervention on the Greek side was decided in London, and in October, it came into being at the naval battle of Navarino. General Richard Church, the Philhellene Chief-Commander of the Greek Army, had already begun to recapture Roumeli. ${ }^{15}$ Then the Russo-Turkish War that broke out in April 1828 and the Russian advance during the following summer made crystal clear that Greek independence was forthcoming and war activities were inevitably coming to an end. Defeated and broken the Empire was badly in need of manpower but could not afford it. The unpaid Albanians in Ibrahim Pasha's Egyptian army in the Peloponnese began to desert and negotiated with the Greeks the very castles they were supposed to guard. ${ }^{16}$ Mustafa Pasha Busatli of Skodra asked for territorial concessions to move his Geghs against the Russians. The Tosk beys stubbornly rejected Kütahı's pleas for assistance while he was trying to hold back the Greek invasion deep into the mountains of Western Roumeli. Instead, they had started pourparlers with the Greeks. Some were ready to trade their keeps and lands for a huge amount of cash. Other beys set off against the Greeks only when the Serasker moved to the Balkan front in March 1829; but it was too late. ${ }^{17}$ The towns of Roumeli were turning Greek one after the other, without any serious resistance by their Albanian guards. Aslan Bey's sudden and successful intrusion to the south, as far as the still Ottoman-held Athens, was not destined to change the outcome of the war. His compromise at Petra was almost inevitable. Busatli's forces had also retreated from the Bulgarian front against the wish of the Ottoman generals. ${ }^{18}$ The provision for a Greek-Ottoman boundary running between the gulfs of Volos and Amvrakikos, which was decided at Adrianople, was the fatal blow. Roumeli was lost for the Empire, seemingly for good, and Albanians had contributed significantly to that end, although this region was of vital economic interest for them. How come?

7 In the summer of 1826 , it became clear in the bloodiest way that the Porte was determined to form a regular army. This was a severe blow not only for the Janissaries but also for the Albanians, whose social structure depended heavily on the mercenary system. The prestige of the clan leaders was related to the number of their armed followers and their economic welfare to the advance payment forwarded to them by the Porte in order to recruit and sustain soldiery. Only a portion of this capital they gave cash to their men; the rest was borrowed with interest until the campaign was over and the accounts settled. As a rule recruits were less than those promised, thus permitting additional profit for contractors. Ransom, income generated from slave trade and other spoils, were extras, which warlords and their followers counted upon to make ends meet, especially if advances were delayed. As the Greek war was ending, this profitable system was also coming to an end. By that time, the Porte had already contracted a huge domestic debt of millions to Albanian veterans, which it was unable to cover..$^{19}$ Breaking up was not a priority for the prudent leaders. They had to buy time. In 1828, Mehmed Reşid managed to regain the post of vali in Ioannina and to oust 
Omer Vrioni. A compromise was reached at the highest level in Constantinople to appease the Albanians. Indirectly it prolonged the mercenary system in exchange for delayed payments..$^{20}$ The Serasker was still supported by a few beys, not all of them very influential. Veli Bey Yadji and his brother Muslim, Bekir Agha of Papouli, Suleiman Bey of Konitsa and the respectable Tahir Abazi, the ablest veteran chief of Ali Pasha, were among them. ${ }^{21}$ Yet, these beys and their local commanders could not guarantee the discipline of the unpaid troops. The latter either levied onerous irregular taxes on Christians to compensate themselves or deserted their posts to avoid engagement with the Greeks, then approaching the gulf of Amvrakikos and moving to the mountainous region of Agrafa. Veli Bey's own forces were insufficient to strike back. ${ }^{22}$

All this did not imply that Albanian power had evaporated or that their wealth had been entirely exhausted. It was there, but it was outside Kütahı's reach, in the hands of an informal anti-Ottoman confederacy headed by the wealthy Iliaz Bey Ziliftar Poda, once the right hand (sword-bearer) of Ali Pasha, an expert in conspiracies and politics and less so in military affairs. He had deserted and had been denounced by the Porte in $1823 .{ }^{23}$ On his side stood Sahin Bey of Delvino and Ismail Bey of Vlora, scion of an illustrious family. ${ }^{24}$ The most efficient military commanders of the confederacy were the aforementioned Aslan Bey Puzzi and his brothers Ragib and Kaplan. It could be argued that these men were following roughly on the tracks of Ali Pasha. Poda was steadily encouraging a rapprochement with the Roumeliot chieftains, his old acquaintances from the court of Ali; Sahin and Ismail were in contact with Kapodistrias's elder brother, Viaros, in an attempt to rekindle Albanian-Greek relations and possibly to co-ordinate military operations. ${ }^{25}$ However, they were not looking for a formal and binding alliance with the rebels or desired to live under Christian rule, as Mehmed Reşid suspected. In a letter addressed to other beys, Ismail vliora stated that the Albanians would deal with the Greeks once they had protected their fatherland (vatan) and put their own miserable house in order. This should not be interpreted as a call for Albanian national independence. What they really wanted was to have a word in Ottoman politics and to retain their military hegemony. As forced conscription to the regular army (nizam) was an imminent danger, Vliora urged them to stand up against the Serasker, who was determined to subdue Albania. Vliora was not an easy prey for Kütahı but eventually he was murdered in January 1829, following an impressive and cunning conspiracy. ${ }^{26}$ Shortly afterwards Mehmed Reşid was appointed Grand Vizier and left for the Russian front. Aslan Bey, Ziliftar Poda and their followers were at large, trying to make the most out of this period of anarchy; at times, they were active against the Greeks but steadily refused to support the Serasker's plans. As rumours about the collapse of the front in Bulgaria spread, this opportunistic attitude was shared by a growing number of Albanian beys. There was a widespread impression of a forthcoming and generalised revolution that expected its natural leader to break out. It was common knowledge that this was the mission for Mustafa Pasha Busatli of Skodra. No one else could equal his wealth and power or his political connections in the Balkans and Egypt. ${ }^{27}$

9 Judging the policy of the anti-Ottoman Albanian party is impossible without a fair knowledge of the Greek camp in Roumeli. After the fall of Missolonghi (April 1826), the Greek struggle entered a most critical stage. When the Acropolis in Athens fell in late May 1827, few people believed that Greece had a chance to become a sovereign state and even less, that Roumeli would be part of it. The captains of the armatoles had to decide their future with caution. Their status as men of war depended on specific 
provinces, which their ancestors and they had been policing for generations, some times for centuries, under the auspices of the Porte and most lately by the grace and direct control of Ali Pasha. Within these provinces laid the lands and pastures they controlled and other sources of income, like tax-farming, which secured their own welfare and the maintenance of their armed followers (palikaria). A network based on intermarriage and on various other forms of social bonding protected their rights from usurpation. Alliances with the Albanian clans were also indispensible for survival at times of war and peace. Without allegiance to Ali Pasha, any warlord and his clan were doomed. The well-known sufferings of the Souliot clans bear witness to the misfortunes of neutrality. After Ali's death, however, the practice of switching camps was in full swing..$^{28}$ In 1826-27, the restoration of Ottoman control in Sterea Hellas made certain that the armatole captains would have to take care of their own, of their followers and of their provinces. Capitulation, genuine or invented, was a traditional practice, a sign of wisdom rather than of cowardice. Of course, in the days of national revolution, capitulation could be and indeed was interpreted as treason; yet to several captains it looked a good idea at the time. ${ }^{29}$

But then, in a few months time, the tide of war changed against the Ottomans and the successful expedition of Church in western Roumeli, encouraged some of them to reconsider. They did not disengage from the Ottoman camp all at the same pace nor with the same conviction. They had to play safe since there was no reassurance about the future frontier of Greece before the Treaty of Adrianople. Loyalty to the Porte could be used as advantage to resume their services. Their future prospect in the Greek camp was unclear, as Governor Kapodistrias was determined to turn the revolutionary forces into a regular army. 'Regularity' implied limited placements for officers, especially for high-ranking, the formation of units with registered soldiers, and a centrally controlled accounting system that would rationalize the flow of salaries. None of these measures was tempting but several chieftains gave it a try, motivated more by the favourable frontier provisions of the third London Protocol (March 1829) and less so by bribes in cash. Their contribution was crucial for tipping the balance of power as the Ottoman side was falling apart. It was a matter of impression first of all. It was common knowledge that they wouldn't have changed sides unless they were convinced that the insurgents would prevail. The armatoles' active but risky participation was expected to secure more territories for Greece. But they were useful in an additional way. They easily convinced their Albanian former comrades to quit unpaid resistance in exchange for a safe passage out of the besieged strongholds, which they personally guaranteed as trusted go-in-betweens. It was in this context of unofficial compromise and military disarray that the Albanian anti-Ottoman confederacy sought, throughout 1829, to recruit Greek allies against the Porte. As they were drifting apart from the Sultan, they assumed that the Greeks, then being on a weak offensive, had all the necessary motivation, as a state in the making and as individual marauders, to secure solid support for another round of warfare, expected to facilitate a common yet extremely ill-defined cause. They were only partly correct in thinking so. ${ }^{30}$ 


\section{The treaty of Adrianople, the new frontier and the former armatoles}

11 The Treaty of Adrianople was officially announced in Ioannina only in late January 1830. A few days later with the fourth Protocol of London, the Greece of Adrianople was shrunk in exchange of independence free of tribute. The new frontier would follow the flow of Spercheios and Acheloos, thus leaving to the Porte a considerable part of central Roumeli, including some places of strategic importance, and most of western Roumeli, i.e. Northern Aetolia and Akarnania. This sequence of diplomatic events over a period of more than six months (September 1829-May 1830) and the rumours preceding and following it fed both Greek and Albanian unrest, which soon turned into anger and despair over the loss of territory. Evidently, Church's last campaign had been in vain. Subsequently he resigned his post, blamed Kapodistrias for the compromise, initiated a movement of protest among the warlords of Rumeli and, in May 1830, published a report entitled Observations on an Eligible Line of Frontier for Greece as an Independent State. Church placed much emphasis on the unjust disappointment of the brave Roumeliot veterans, who had to retreat and surrender their land to the defeated Albanians. ${ }^{31}$ As prospects changed, keeping the veteran captains who had sided with Church on a short leash became a complicated issue. In late 1829, as warfare had officially ceased, Augustinos Kapodistrias, the Governor's younger brother, took over the task to re-organise the Greek regular army. His plan was flexible enough to provide honorary and other policing positions in light units for the surplus of chieftains and to appease even those who had most recently been attracted to the Greek cause. Encouragement implied even paying a few reluctant captains. ${ }^{32}$

Yet, it was impossible to satisfy them all. When the first regular light battalions were formed, dissatisfied, and redundant warriors and chieftains sought alternative careers with the Ottoman Empire. As the armatolik system was reinstated everywhere, reclaiming their family rights and offices in their distant homelands, in Thessaly and Macedonia, was not meaningless. The same was true for the famous Agrafa armatolik, for the time being a no-men's land, partly or wholly outside the Greek frontier. One of the local chieftains, Sotiris Stratos, although despised by the locals, was tolerated and given offices by both Greek and Ottoman authorities, for keeping his province neutral. ${ }^{33}$ The really tough question, however, was faced by the former armatoles of those regions that Greece was expected to hand over to the Porte following the last protocol. They were still in control of the tax-framing system and had managed to embezzle part of the tributes, yet not without disputes with the central government. These men as a rule belonged to Kapodistrias' opposition, led by Ioannis Kolettis, a former doctor in the court of Ali Pasha of Vlach origin and a well-known expert in political intrigues. ${ }^{34}$ For the time being their mentor was inactive, hoping for an appropriate office by the Governor. Should they also stay idle? Should they challenge diplomacy with arms and join the rebel forces of Ziliftar Poda or renew their allegiance to the Sultan in exchange for profits that Kapodistrias was unable or unwilling to cede?

The Governor knew these veterans could not be trusted. His special commissioner to western Greece, the educated and widely-travelled Konstantinos Rados, and the chief commander of the army units in the same region since September 1829, the Neapolitan experienced officer Vincenzo Pisa, were closely monitoring the veterans and reporting on their whereabouts. Kapodistrias was anxious to curtail any 
communication between the Greek captains and Mehmed Reşid, which could have been interpreted as evidence of loyalty to the Porte and of his own weakness to inspire order. What he was afraid of - in addition to local conspiracies and mutinies- was Ottoman retaliation in case these captains were involved in Albanian uprisings. A successful Ottoman invasion would eliminate any hope of altering the course of diplomacy in favour of Greece and would render the delivery of western Roumeli as well as his own demise inescapable.

On the other side, the Grand Vizier, his son Emin Bey, stationed in Ioannina since April 1830, Mahmud Hamdi Pasha of Larissa, an efficient Circassian loyal to Mehmed Reşid, and Veli Bey Yatzi were all working for exactly the opposite cause as firmly as Kapodistrias. In fact, the policy of shaking off Greek political influence in Roumeli had begun much earlier, but was renewed and reshaped after the Russo-Turkish War and the fourth Protocol. In addition to re-allying with the armatoles, the Porte sought to restore law and order in its western provinces. Measures regulating taxation and tributes were issued. Relevant circulars were dispatched to all provinces, assuring the Sultan's subjects that his primary concern would be to alleviate the distress of the poor and to treat the Christians as equals. Flattering and threatening letters in equal measure were delivered to persons of influence. False rumours were disseminated to increase pressure. Declarations of loyalty to the Sultan were demanded and extracted. Regaining the allegiance not only of the warlords but also of the Greek notables, particularly in Roumeli, was essential for the smooth transition of power and for reducing emigration from the Empire to the Greek state, a threatening and easily observed sign of ill-administration. However, none of these measures was bound to bring any results as long as the Albanian mutineers were ravaging the provinces. Beating them down was not an easy task. ${ }^{35}$

In 1830 Albanian rebels continued to fish for allies on the Greek side but they were running out of time and space as both the Greek and the Ottoman camp closed their ranks. They were dragged into an intra-armatoles clash in Agrafa, albeit without any strategic gains. Aslan Bey managed to recruit a few hundred Greek bandits (listes) led by a certain Theocharis but to no avail. Mahmud Hamdi Pasha struck an early blow to the rebels in April 1830, near Tsaritsani, in a passage between Macedonia and Thessaly. Ragib and Kaplan, the brothers of Aslan Bey Puzzi were severely beaten-up. Hundreds were killed and wounded. Aslan Bey, then in Lamia, had to manoeuvre through Greek territory to save himself and his followers. As Thessaly was being cleansed from the Tosk rebels, he and his new associate Tafil Buzi, once a follower of Omer Vrioni who had sided with the Greeks, ravaged the town of Kozani in south-west Macedonia. They were forced to evacuate it after a month of pillaging. ${ }^{36}$

The Chams, yet unaware of Aslan's accumulating troubles, were also on the move, besieging the pro-Sultan guards all around Epirus. Ziliftar Poda was on their side and Mustafa Pasha of Skodra was still expected to put his weight and overwhelm the Ottomans. But the Chams were frustrated (or perhaps relieved) in the most unexpected way. Veli Bey Yatzi, who had been almost useless to the Grand Vizier so far, managed to come to terms with Aslan Bey. By that time Kütahı had established his position in Bitola escorted by units of the newly formed regular army. What followed is not unknown to historians. The vizier mustered in that town notable Christians and Muslims alike to indoctrinate them into his new mode of administration and the Albanian chieftains were paid their long due salaries. After massaging the Albanian chieftains with pardons 
and bribes for several days, on 9 August 1830 he summoned them, supposedly to attend a ceremonial salute parade of the regulars, and shot dead some hundreds of them, including Aslan and Veli. Their severed heads were duly salted and sent to Constantinople for exhibition. Two days later Emin Bey, the Vizier's son, ambushed and killed Veli's brother inside the fortress of Ioannina. Prudent Poda did not attend the Bitola meeting and was saved. Aslan's brother Ragib, then in Ioannina, declined Emin's invitation and also escaped slaughter. Mustafa Pasha and his Geghs army had not interfered at all. ${ }^{37}$

The Tosks were puzzled and enraged by Mustafa Busatli's treason and the Grand Vizier's treachery; but they did not despair, at long as Ziliftar Poda was on their side. Their beys attended meetings, took oaths of revenge, and summoned their forces. They also sought assistance from the Greek side: the emigrant Souliots, the Christians of Himarë, even from Governor Kapodistrias. They received none. Kapodistrias explained to the two Cham beys who had written to him that peace with the Ottoman Empire had been restored and that its breach was against Greek interests. ${ }^{38}$ Poda did not renew his efforts to save himself from extinction and his son, then a hostage in the hands of the Vizier, from death. The decisive moves of Kütahı during the fall of 1830 discouraged all his opponents. His pashas moved swiftly and, assisted by the Greek armatoles, began to re-occupy Epirot towns and fortresses, and to replace irregular with regular guards..$^{39}$ In the following weeks, as the forces of Mahmud Hamdi moved to the Berat region to confiscate the properties of Aslan and Veli, the flow of the rebel beys and their families to the nearby island of Corfu escalated..$^{40}$

When he had left Ioannina for Bulgaria eighteen months earlier, Kütahı had promised with tears in his eyes to take revenge of the mutinous Albanians. He kept his promise. But this did not suffice to satisfy his master. His return from Bitola to Epirus ought to signal the restoration of rule and justice and he worked intensively to this end. Letters of amnesty were sent anew around Roumeli, within and outside the Sultan's domains. He invited the people of Parga, who had taken refuge in Corfu 1817, to return to their homeland and encouraged pastoralists from Akarnania (Greek territory) to use their usual mountain summer pastures in Ottoman held Epirus. For local Christian notables and Muslim beys he reserved a mixture of flatter, pressure, threat and, mostly, punishment. This is what he knew best. All those who had made the poor people suffer in his absence would have to pay dearly. ${ }^{41}$ Terror spread amongst them. After the Grand Vizier's return to Ioannina (October 1830), nobody who had taken arms against the Sultan risked to approach him in person to ask for pardon or to negotiate a compromise; least of all the unscrupulous armatoles, who had been flirting with all sides. As winter approached, they were all asked to reduce their forces to a minimum. They were threatened but they did not succumb. In wintertime, armatoles were untouchable. ${ }^{42}$ The diplomatic process was also coming to an end. Despite Greek disillusion, Akarnania was due to be evacuated by the Greek armed forces and handed over to the Porte in exchange for Athens and Euboea. Details were being arranged as a simultaneous transfer had been agreed upon..$^{43}$ The British Consul in Preveza, Edward Meyer, announced that perfect calmness had eventually been restored in Epirus after a decade of warfare. ${ }^{44} \mathrm{He}$ could not have been more wrong. 


\section{Turbulence, violence and insecurity}

19 It was only a few days later, on 12/24 December, that the Grand Vizier stunned once more everyone. After detailed planning, he launched a surprise attack against all the active armatoles in Macedonia, Thessaly, and Epirus. Some of them were invited to receive their orders in person and upon arrival were murdered; others were ambushed at home or encircled at their hiding places by troops sent against them following a wide strategic plan in which the cavalry and the navy were also involved. In the following days and weeks, the initially clandestine operation evolved into a campaign with severe collateral damages, from Mt Pelion to Halkidiki and to Agrafa. In the latter, Ottoman forces, supported by a strong local militia recruited by a local Greek notable, swept the armatoles out of the region. Hundreds were killed during these mid-winter operations but only a few captains, most likely less than ten. Some of them, like the armatole captains of southern Macedonia, managed to escape thanks to the speedy mediation of the Russian and the French Consuls in Salonica to the Grand Vizier and the hefty purse delivered to the local pasha. ${ }^{45}$

Not unlike what had happened in Bitola, the attack was directed against all the armatoles, regardless of their actual stance during the previous months. Petitions against them signed by village notables had been extracted and collected in advance. Kapodistrias had been briefed by the Grand Vizier on the sufferings caused by brigandage and had agreed to refuse them entry to Greece when pursued by the Ottoman army. When the powers protested for the unnecessary bloodshed, the Porte presented sufficient documents to prove that it was for a good cause and with Greek approval, from top to bottom. ${ }^{46}$ The trick was that the armatoles in the service of Porte were deliberately confused with thieves, robbers and brigands; they were called listes $(\lambda \eta \sigma \tau \dot{\varepsilon} \varsigma)$, a pejorative term employed instead of the well-know term kleft, a synonym of freedom fighter. Even if they deserved this confusion, still, for the time being, most armatoles were in reasonable if not in good terms with the Ottoman administration.

21 In the following months, as a wider Albanian revolt broke out, it was thought that the December attack against the armatoles was a pre-emptive strike to undermine the Albanian morale and cut short their Christian reserves. This is not a plausible explanation. Had the Vizier foreseen or known the forthcoming open revolt of Mustafa Busatli Pasha, he would have strengthened instead of breaking his ties with the Greek captains so as to secure his back. It is more likely that Kütahı considered this operation as the final stage of a mission assigned to him by the Sultan to clear his domains from all the armed irregulars, Christian and Muslim alike, and to secure a "monopoly of violence" for the Porte. At least this is how he had explained his actions in a letter to the French and Russian Consuls. ${ }^{47}$

Whether in the service of the Porte or not, the captains of the armatoles attracted around them irregulars and outlaws of all kinds; therefore, they contributed a lot to the state of anomaly, which Kapodistrias had exposed as a serious deficit of Ottoman administration and used as an argument against the annexation of Akarnania. In his view, local turbulence and insecurity were signs that the Porte did not possess the moral right to rule. Diplomacy was pressing the Ottomans in an additional way. Lord Palmerstone had already informed Kapodistrias that the fourth Protocol might be revised in favour of Greece and had advised him to postpone the evacuation of Akarnania..$^{48}$ The Grand Vizier had to move fast in order to eliminate any possible gap 
that Kapodistrias might exploit. Yet, he had failed to accomplish his task. Most of the captains were at large.

Kütahı's new act of dishonesty unleashed the rage of the surviving Greek irregulars, armatoles and bandit thieves alike. As snow on the mountains began to melt, in early spring 1831, they came out of their hideouts and mustered anew, ready to extract revenge and per chance, after an honourable compromise, get their armatoliks back. Surviving captains were joined by the followers of the deceased and by many more common thieves from the Greek territory who foresaw a unique opportunity to plunder and pillage. Unpaid deserters from the Greek battalions, unemployed Souliot worriers, and young pastoralists merged with them; thus, by late spring, their marauding bands counted thousands of men. ${ }^{49}$

This flow of men cannot be explained unless certain events are taken into account. From the early months of 1831, it was rumoured that Busatli Pasha would launch his long expected attack against the Grand Vizier. Ziliftar Poda, having freed his hostage son, was also expected to participate. Both leaders were in contact with the Cham refugees in the Ionian Islands and in Missologhi and had sent envoys to Greece, even inside the military camps, to recruit warriors. The Albanians and their allies were definitely supported both in theory and in practice by the circle of the discontent captains in Akarnania, the aforementioned opponents of Kapodistrias, who wished to renew the revolution and push Greek frontiers to the north against the provision of the last protocol. This is why the Greek brigand forces carried banners with the cross and portrayed themselves as liberators who had been pursued by their own government and forced to seek a better fortune in the Sultan's domains. In fact, in May 1831 an army mutiny broke out against Kapodistrias. He managed, however, to preserve the control of all the battalions, while the mutineers merged with the brigands. However, enthusiasm was still running high as news were coming announcing the sacking of numerous Ottoman towns and villages and, most of all, the eventual involvement of Busatli and Poda. Christian brigands joined their forces with Albanian rebels and became even more daring. ${ }^{50}$

Yet, despite the initial enthusiasm, the timing was far from perfect for the rebels. Mustafa Pasha had been preparing his come back, at least since January 1831. He had tried to secure support of every kind from Serbia, Egypt and Bosnia, mostly from the Bosnians, who shared his detest for the nizam..$^{51}$ Open warfare, however, began in the end of March when he moved to the south and occupied Skopje. Among his allies were also some Albanian ayans of Macedonia -one of them, Ali Bey Karafejzić of Tetovo, plundered the bazaars of Sofia- and the expatriate Peloponnesian Tosks of Lala. The Grand Vizier rushed to Bitola while major towns in Thessaly and Southern Macedonia were falling easy prey to the rebels. The odds were against him but he defeated Busatli and his Geghs twice in less than two weeks. Mustafa fled to Skoutari. ${ }^{52}$ By that time, Poda had hardly moved his forces. He was checked and then besieged in his castle by Mahmud Hamdi Pasha of Larissa. The northern front had not been cleared yet - the Bosnians were coming and Busatli Pasha was still active. Yet in May the Grand Vizier was in a position to mobilise under the threat of severe punishment his old associates in Ioannina and put them urgently against the Greek-Albanian brigands, still unaffected by the course of warfare in the north. It was not an easy task, yet it was accomplished before the July revival of Cham revolutionary activities in Epirus, the Bosnian victorious offensive and the surprise exodus of Busatli's besieged forces in 
Skoutari. By the end of June 1831, the main force of the Greek and Albanian brigands had been defeated and broken into small bands, vexatious but unable to pose a serious threat. Tafil Buzi and Aliko Liamtze, an uncle of the late Aslan Bey Puzi, were leading the strongest of them but proved unable to break through and assist the besieged Poda. Apparently, the rebel forces and their allies were hardly coordinated..$^{53}$

As far as the Greek brigands were concerned, lack of coordination was only one of their problems. Of greater importance was the growing lack of support from the local Christian population. Christian villagers within the Sultan's domains were unwilling to see the brigands' power restored. They could no longer afford supporting them. At the same time, on the Greek side of the border their recent burst for revolutionary glory could not erase the stigma of Turcophilia. They had been deprived of state recognition and protection both in Greece and in the Ottoman Empire. Without Greek or Ottoman commission, they were not different from common outlaws on both sides of the border. ${ }^{54}$ This view was shared by both the Grand Vizier and the Greek Governor as mentioned above. The cooperation of the two leaders for the annihilation of brigandage, though not really desirable, was inescapable. The Ottoman Empire and nascent Greece had to act like modern states in spite of recent bitter memories. By the time (June 1831) the brigands were defeated by the pashas who were sent after them, some progress had been made to restrict their movement, albeit it was not impressive. Their annihilation could not be realised as long as Greece would let them cross the border and seek refuge.

\section{"Robbery" and negociations}

Kütahı and his son Emin had begun to exercise considerable pressure on Kapodistrias soon after the initial attack against the armatole captains in December 1830. The

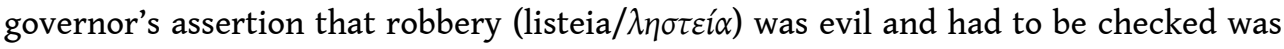
taken as an official commitment to support Ottoman endeavours and his later promise to seek out any intruding outlaws and force them out of Greece was interpreted as a guarantee for a relentless pursue. Yet soon, Emin Pasha was able to produce ample and detailed evidence that the governor could not keep his promise and conform to Ottoman expectations, although Ottoman aims were in line, in Emin's view, with international law..$^{55}$

Ottoman allegations were employed by Kapodistrias to strengthen his case. He admitted bluntly his inability to control the border. He had tried hard and had documents to prove his willingness but he had limited resources. War and anarchy on the other side of the border, he argued, appealed to men who had warfare as their profession and weapons as their tools of trade. He suggested a rearrangement of the frontier line so that it would become defensible and controllable from the Greek side or else the hunting down of the brigands should be assigned to French troops. Both Kütahi and Kapodistrias were aware that in essence their correspondence and arguments on brigandage were linked to the larger and pending debate about the future frontier line. In this context, they both wanted to make clear that they were able to govern effectively their domains. Their shortcomings, therefore, were attributed mostly to each other. Yet, Kapodistrias knew that his arguments, no matter how suitable they were for the Europeans, were not going to save his country in case the Grand Vizier, in his anger and despair, ordered an invasion of Greece to hunt down the brigands. This was his constant and not entirely unsubstantiated concern. In May 1831 Kütahi asked 
him to urgently choose between stopping the brigands' entry or allowing the Ottoman army to chase them inside Greece. His letter was also communicated to the European courts. In a final attempt to buy time, Kapodistrias proposed sending a mixed committee to negotiate with the Grand Vizier in Bitola. This was the civilised way to handle the issue..$^{56}$

The mission was assigned to Senator Ioannis Karapavlos, a close political friend of the governor, a notable of Koroni, who was escorted by the Russian Consul Ioannis Paparrigopoulos and the British Consul General William Meyer, an old acquaintance of the Grand Vizier since 1828. The Greek proposal consisted of three terms:

- All possible efforts would be made to stop the entry of brigands and rebels and to keep the intruders away from the border zone,

- Brigands' families would be relocated to Peloponnese or to the islands or else they would have to leave Greece,

- To the extent that the spoils of looting could be distinguished from legal merchandise, such spoils could not be traded inside Greece..$^{57}$ The party moved from Nafplio to Ochrid via Missolonghi, Prevesa and Ioannina but when they arrived, three weeks later, the Grand Vizier was not there. He had departed on the eve of their arrival to face the Bosnian attack threatening Skopje.

In his stead Hati effendi, special envoy of the Porte, carried on the negotiation for two weeks. They reached a standstill when it became clear that the terms under discussion were not the same as those submitted by Kapodistrias to the European ambassadors in Constantinople. The latter had provided for the arrest and deportation of all those who would seek refuge in Greece. The return of the defeated and angry Kütahi two weeks later did not facilitate the negotiations. He would not accept anything less than the firm closure of the border, the arrest and deportation of the runaway rebels and robbers and the payment of indemnities by the perpetrators for damages caused. Even the entry of the Ottoman army into Greece as an ultimate measure was still on the table, though not submitted in writing. The mission of Karapavlos turned out to be impossible..$^{58}$

31 As soon as the envoys reported what had been discussed at Bitola and the new terms of the Grand Vizier were announced, Kapodistrias began preparing a feasible counter-proposal, which he communicated to the Powers. He made clear to his political commissioners and to his officers that if they did not follow his instructions to watch closely over the intruders and deport them the "most essential interests of the state" would be endangered..$^{59}$ The negotiations had been a failure by all accounts save one. The Greek Governor had bought some precious time when it was much needed. In late July, when Karapavlos was debating with Hati effendi in Bitola, the improvement of the frontier in favour of Greece was finally decided in London, that is the restoration of the Adrianople line (Amvrakikos to Pagasitikos). Instructions were dispatched from London to Constantinople in late September. Most likely Kapodistrias was unaware of the details when he completed his counter proposal. It was only five days before his assassination. By that time, both Ziliftar Poda and the Cham beys of Epirus had been beaten up and capitulated to save their heads. ${ }^{60}$ Three weeks later Busatli Pasha also succumbed. A bomb had blown up his gun powder store, in his mighty fortress. He was also pardoned on conditions. 

uprising continued into 1832 and fresh Albanian uprisings took place between 1833 and 1836, Tafil Buzi always playing the leading part. ${ }^{61}$ Illegal border crossings did not cease either and gradually became a permanent feature in Greek-Ottoman relations and a prerequisite of state sponsored irredentism. Soon after the assassination of Kapodistrias, Greece was dragged into another round of civil strife between the adherents of a Constitution, with pro-French and British leanings, and the pro-Russians, the followers of the Kapodistrias family and Kolokotronis. Needless to say, Kolettis and his Roumeliot armatole clients constituted the hard core of the former party. In this chaotic period (autumn 1831-winter 1831-32), numerous brigands easily crossed the frontier and some of their captains, Buzi included, were recruited as army officers by the opposition. ${ }^{62}$ The Grand Vizier kept a low profile until he had to depart for Syria (spring 1832) to tackle the Egyptian invasion, coming too late to influence Albanian affairs. He watched the capitulated Albanian chieftains, especially Poda, who had sought shelter in Greece instead of going on a pilgrimage to Mecca as he had promised, and in vain protested to the Greek government; but he did not dare to intervene, as Kapodistrias had feared. ${ }^{63}$ As a serasker of the old regime, most likely he wished to crash these brigand captains who were getting in his way for a decade or so and accomplish the task once assigned to him by his Sultan. As a Grand Vizier, he knew that the days of brutal suppression were gone. The independence of Greece under King Otto was decided on 29 April/11 May 1832 and the remaining details of the frontier line four months later. All the Ottoman Empire could do was to behave and to reform.

Although the problem of brigandage was not of the same scale for Greece and the Ottoman Empire, considering the general dislike of nizam in the Balkans and the extensive fighting to impose the will of the Sultan, both Governor Kapodistrias and Grand Vizier Mehmed Reşid did their best to solve it in a European like manner through diplomatic means. What was at stake was not merely to bring to end brigandage and deal effectively with beys and chieftains, Muslim or Christian, Albanian or Greek. Who would control the new borderland, a by-product of the Greek Revolution, was of outmost importance in the minds of both sides. New frontiers went hand-in-hand with new borderlands; a borderland between a new state, tormented by domestic political strives, Hellas, a crumpling Ottoman Empire, trying to pull itself together, and an Albanian indirect yet violent claim for some kind of territoriality. As diplomacy protracted, a much larger area acquired the characteristics of a borderland, since none of the three interested parties could impose its control. Its size was unspecified, Sterea Hellas, Thessaly, Epirus, South and North Macedonia, Albania, Bosnia.

\section{Albanians at the heart of the problem}

Albanians were at the heart of the problem. Vague signs of nationalism could be traced in the plans, letters and sayings of some of their leaders, Geghs or Tosks, but it is hard to argue that as a whole they were pursuing a national project. On the contrary, their beys and clan leaders were bound with bonds of blood and divided by vendettas. The number of their paid followers determined the social hierarchy of these networks. Leadership depended on the size of the purse. Thus, as stated above, their common and 
most serious concern was to keep alive the mercenary system, not to build a state. Their care for the preservation of the Islamic or any other local tradition reflected nothing more than this major financial concern. Tosks and Geghs sided with or against the Grand Vizier, with or against each other depending on the flow or the promise of salaries. If the Porte paid them, it could easily regain their loyalty. If not, they could and they did-side with the Greeks without any religious reservation; yet this choice was tactical, an emergency solution for the rebels, not a sign of national convergence; unless the Albanian speaking Greeks (the Souliots included) were willing to renounce their recently acquired Greek veneer and turn Albanian.

In order to escape the stigma of Islam Tafil Buzi, who invested heavily on the Greek camp, identified himself as an Epirot, a descendent of the ancient King Pyrrhus and the early modern Christian Albanian warlord Skanderbeg. ${ }^{64}$ For other Albanian beys of his rank such arguments were redundant. Usually they tried to exploit old bonds of friendship, trust, alliance or the handy memory of Ali Pasha; a cause that did not necessarily reflect a real past but was socially acceptable. In any case, in the absence of regular payment, Albanian rebels were not in need of an alternative state mechanism. Looting and taxing freely an increasingly extensive region, from Prevesa and Trikala to Sofia and Skopje, especially the urban centres, made up for the loss of salaries.

Next to and in contact with the Albanian rebels was the world of the Greek palikaria, the klefts or listes, the armatoles and their captains (kapetanioi), also dressed in their once white kilts and no less unwilling to replace them with any kind of European uniform. In this world, as stated above, flexibility was also a virtue necessary to survive, in addition to networks of power connecting chieftains, followers, political patrons, friends, and relatives. After ten years of warfare a surplus of armed palikaria had been created; young professional warriors, mostly Roumeliots, Epirots and Macedonians, unable to secure their living in peacetime. The light Greek battalions were an option after 1829 but there was not enough room for hundreds of them or good prospects for regular remuneration. The same was true for their angry captains in search of high offices, which could prolong the irregular taxation of their respective provinces and the payment of their soldiers. Did they have a better option outside Greece? Both the Ottoman army and the Albanian rebels of Poda appeared willing to compensate them for their support. They could exploit the situation to regain their offices or even extract better terms of employment playing one employer against the other. If the Ottomans eventually re-gained Roumeli, then they would top the social hierarchy, being the ablest and most suitable to rule the Greeks anew. Flirting with the Albanians was indeed dangerous; but at least they could seek refuge for themselves and their families as well as markets for the booty in Greece, behind the frontier line.

The December attack of Mehmed Reşid against friends and foes alike definitely changed the priorities of those who survived. The armatole career had seemingly come to an official end, but they had not run out of options, especially when Bushatli and Poda got actively involved. In this context, Greek brigands, jointly with the Albanians, could loot extensively Muslims and Christians alike. At the same time they could claim they participated in a revolutionary action to force the revision of the onerous fourth protocol, in a protest against the compromising policy of Kapodistrias and in favour of a constitutional government. Thus, they portrayed themselves as ardent nationalists deserving official pardon and restitution, as the impoverished victims of the governor's domestic policy and active members of his opposition, ready to take over the 
government of Greece. Their choice was justified after the Kapodistrias' assassination and even more so during the following decades, as the deeds of the klefts and the armatoles were purified and cherished in the context of Greek irredentism.

Keeping under control and pacifying this turbulent border zone, the habitat of Greek and Albanian military élite, was a complicated task. Neither the Grand Vizier nor the Greek Governor had the necessary capital to buy out the brigand chiefs. For both sides forced conscription to the regular army was the only remedy for disorder but local recruits could not be trusted, having served for a long time as irregulars. Unlike Greece, which depended exclusively on locals recruits, the Empire had the option to move Asiatic troops to the Balkans. But trained reserves were in short supply considering the pressing strategic needs at the time and the novelty of the new model army. As a result, Ottoman regular forces were always outnumbered by Albanian rebels, and irregulars were badly needed to tip the balance of power. Control was not only a matter of military power but also of trust. But trust of the state was in short supply across both sides of the border since the future of those regions had not been decided yet. Kütahı and Kapodistrias relied on a number of trusted military officers, supported by special envoys and administrators (mütesellims in the Ottoman case), to administer taxation and oversee the loyalty of the rest. They also spent considerable effort to massage the notables and the clergy with promises of law and order in order to break loose from the captains' tight control. In this task, the Grand Vizier proved more efficient than the Greek Governor. It was not only a matter of experience. Although his policy was closely monitored by the European powers, he could still employ mass violence and treachery to subdue his opponents as long as he could prove that this was his only option and a prerequisite for the new order.

The efforts to control the borderland would have been more effective if a definite frontier line had been decided. Yet, even in its absence, a sense of territoriality had been developed to the benefit of both the states and the outlaws. The former had to converge over the border in order to secure trade, the movement of transhumant shepherds, passport control, quarantine, and most of all security. These could not be achieved without physical contact between the Ottoman pashas and the Greek majors, without direct or indirect communication between the Governor and the Grand Vizier. Outlaws had also benefited. Ravaging outside the line under the appropriate banner was not an evil act but a manifestation of Greek patriotism. Inside the line, as mentioned above, there was always a safe place for brigands, thieves, rebels and mutineers and chances to trade the spoils of plunder, mostly sheep and goats. Sometimes outlaws were dined, inebriated, and bribed by Greek officers to stay outside Greece and thus negate Ottoman allegations of offering them asylum. This set up involved even virtual skirmishes. On other occasions Greek officers extracted money and treats from the Muslim beys to secure safe pastures for their sheep inside Greece. Most likely, these were not the only occasions to extract bribes and they did not cease when the line was fixed.

\section{Conclusion}

40 To conclude, Greek independence and the end of warfare after the conclusion of the Russo-Turkish war affected in multiple ways the armed Greek and Albanian elites of the region. Territorial demarcation, the attempted restoration or building (in the case of 
Greece) of central control in order to monopolise violence, peace on non acceptable terms, and military modernisation went clearly against their traditional interests. Their world seemed to have come to an end. Their responses turned violent in direct ratio to the threat of extinction they encountered. But this did not imply that they were not willing to compromise. Turning brigand or rebel, as the case might be, were standard practices that facilitated a successful new agreement of terms. No doubt, this attitude was in the mind of everybody from top to bottom, from Mustafa Pasha of Skodra to the last Greek palikari. They did not want to break bad, but to regain their status, influence, and welfare. Only this time the scale was different. Generalised mutiny inside Greece and the Empire was undesirable for the Powers. This was clear to Kapodistrias and to the Grand Vizier. They both proved extremely willing to sacrifice the old élite of captains and beys for the needs of current diplomacy unless they succumbed and obeyed. In an unexpected way, however, the violent reaction of these agents of tradition, regardless of their true motives and slogans, fed back both Albanian nascent nationalism and Greek irredentism and tormented diplomacy for ages. Revenge is a dish always served cold.

\section{BIBLIOGRAPHY}

\section{Monographies}

ALIčǐč Ahmed S., 1996, Pokret za autonomiju Bosne od 1831 do 1832 godina [Mouvement pour l'autonomie de la Bosnie en 1831-1832], Orijentalni institut, Sarajevo, 438 p.

Anscombe Frederick F., 2014, State, Faith, and Nation in Ottoman and Post-Ottoman Lands, Cambridge University Press, Cambridge, 339 p.

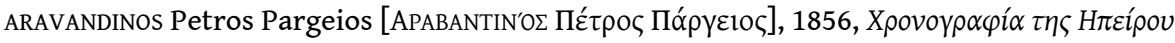

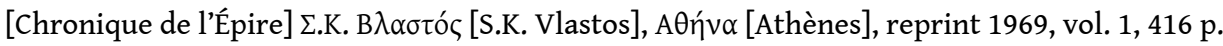

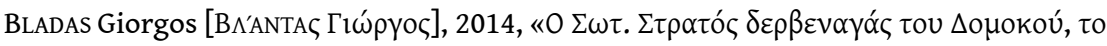

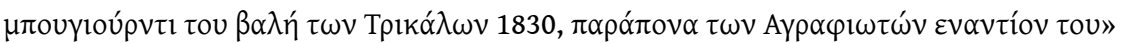
[Sotiris Stratos, dervenagas de Domokos, le bouyourdi du vali de Trikala, 1830, plaintes des

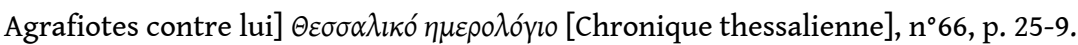

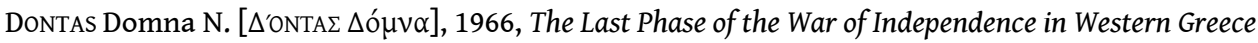
(December 1827 to May 1929), Institute for Balkan Studies, Thessaloniki, pp. 17-85.

ERDEM Hakan, 2007, “'Perfidious Albanians' and 'Zealous Governors': Ottomans, Albanians, and

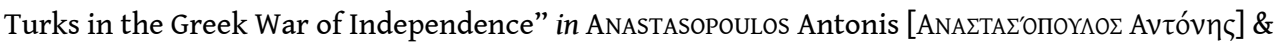

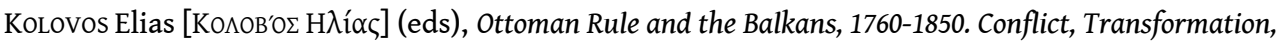
Adaptation. Proceedings of an International Conference Held in Rethymno, Greece, 13-14 December 2003,

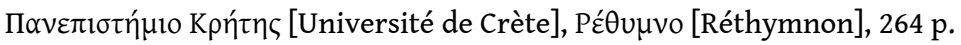

FANSHAWE TOZER Henry, 1869, Researches in the Highlands of Turkey, John Murray, London, vol. 1. 
KAMBEROVIĆ Husnija, 2002, Husein-kapetan Gradaščević (1802-1834) Biografija [Husein-kapetan Gradascevic (1802-1834), biographie], BZK Preporod, Gradačac, 128 p.

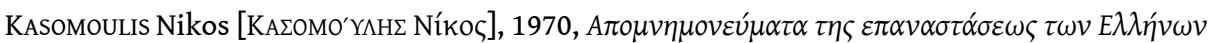

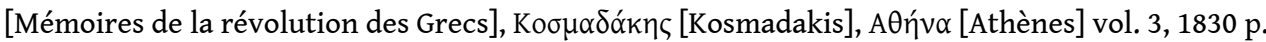

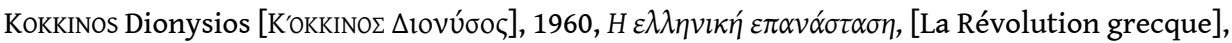

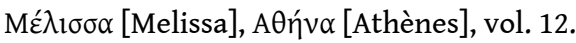

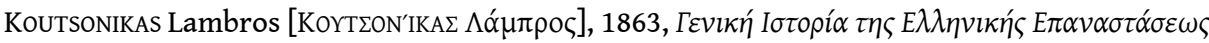

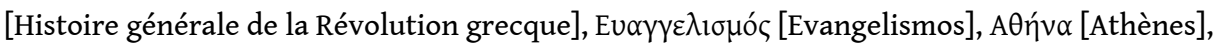
vol. 1, $278 \mathrm{p}$.

LEAR Edward, 1851, Journals of a Landscape Painter in Albania, Richard Bentley, London.

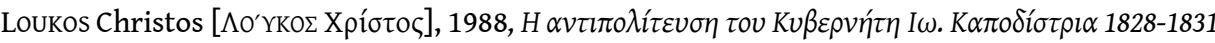

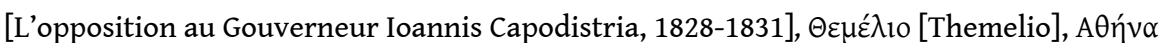
[Athènes], $452 \mathrm{p}$.

MERDJANOVA Ina, 2013, Rediscovering the Umma: Muslims in the Balkans between Nationalism and Transnationalism, Oxford University Press, Oxford.

NACI Stavri, 1986, Pashalleku i Shkodres 1796-1831 [Patriarcat de Shkodra, 1796-1831], Akad. e Shkencave e RPS të Shqipërisë, Tiranë.

NEDELJKović Slaviša, 2015, "Between the Imperial Government and Rebels. Old Serbia during the Rebellion of the Shkodra Pasha Mustafa Bushati and the Bosnian Aristocracy 1830-1832", Istraživanja, 26 (2015), p. 92-3.

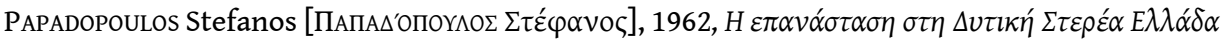

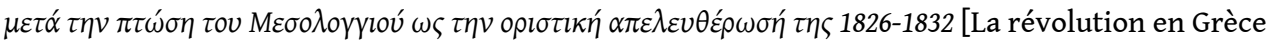
continentale de l'ouest de la chute de Missolonghi jusqu'à sa libération finale 1826-1832]

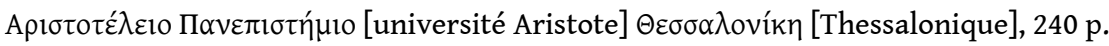

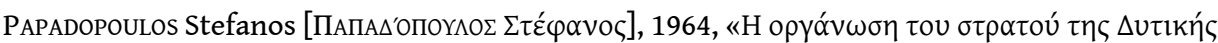

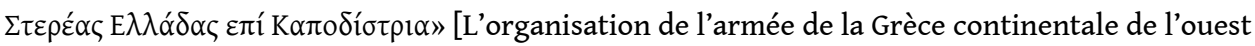

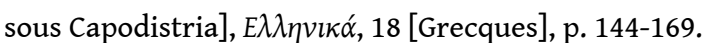

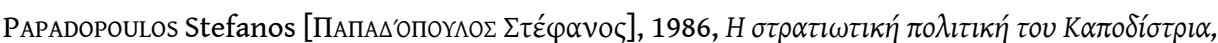

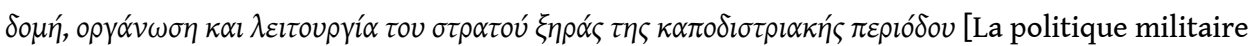
de Capodistria, organisation et fonctionnement de l'armée de terre de la période capodistrienne],

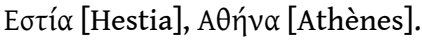

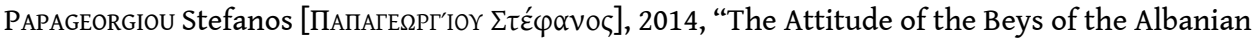
Southern Provinces (Toskaria) towards Ali Pasha Tepedelenli and the Sublime Porte (mid- $18^{\text {th }}$-mid- $19^{\text {th }}$ Centuries) The Case of 'der'e madhe' [Great House] of the Beys of Valona", Cahiers balkaniques, 42 (2014), pp. 2-29.

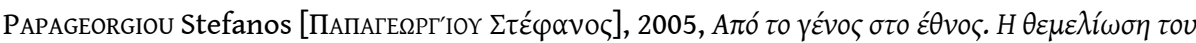

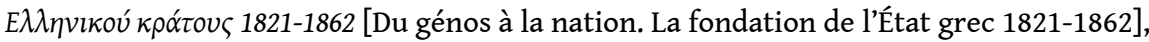

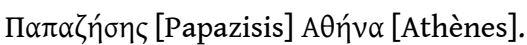

PAPAGEORgIOU Stephanos, 1985, “The Army as an Instrument for Territorial Expansion and for Repression by the State: The Capodistrian Case", Journal of Hellenic Diaspora 12.4, p. 33 sqq.

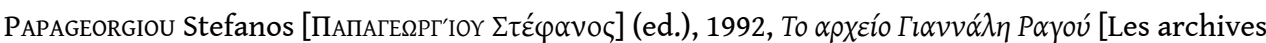
de Giannalis Ragou], IEEE, AӨńv $\alpha$ [Athènes]. 


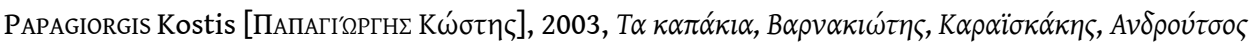

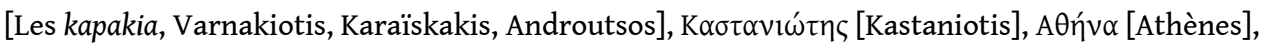
$290 \mathrm{p}$.

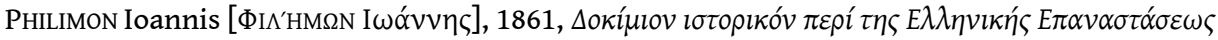

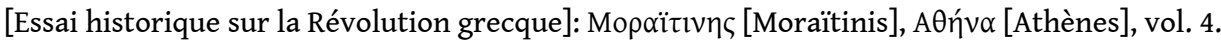

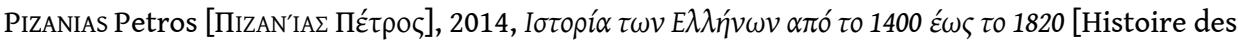

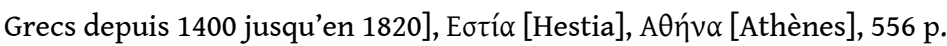

Pollo Stefanaq, 1984, Historia e Shqipërisë: Vitet 30 të shek. XIX-1912 [Histoire de l'Albanie des années 30 du XIXe siècle à 1912, Akademia e Shkencave e Rps te Shqiperise, Tiranë.

SEL TURHAN Fatma, 2014, The Ottoman Empire and the Bosnian Uprising: Janissaries, Modernisation and Rebellion in the Nineteenth Century, I.B.Tauris, London, 336 p.

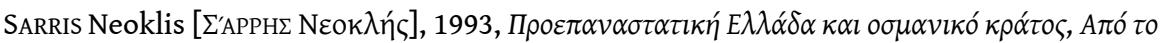

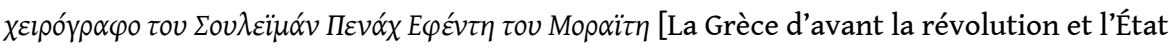

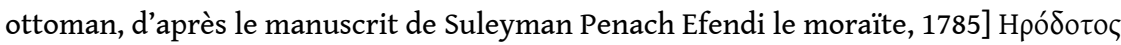

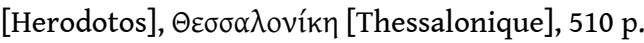

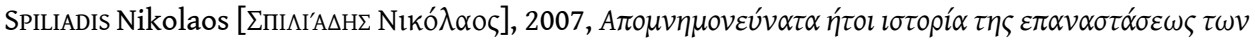
$E \lambda \lambda \eta v \omega \nu$ [Mémoires c'est-à-dire histoire de la révolution des Grecs], CHRISTOPoulos Panagiotis F.

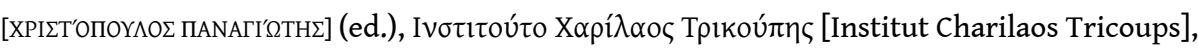
AӨńv $\alpha$ [Athènes], vol. 4, $3142 \mathrm{p}$.

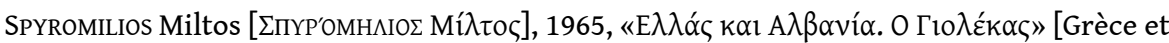

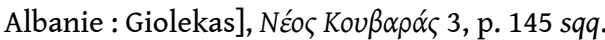

THËNGJILLI Petrika, 1981, Kryengritjet popullore kundërosmane në Shqipëri, 1833-1839

[Contre-insurrections populaires en Albanie, 1833-1839], Akademia e Shkencave e Rps te Shqiperise, Tiranë.

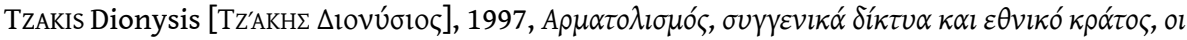

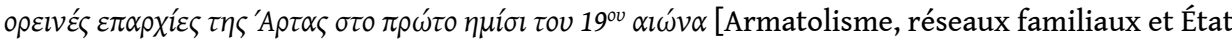
national, les régions montagneuses d'Arta dans la première moitié du XIX ${ }^{e}$ siècle], unpublished PhD diss., Panteion University, Athens.

URQUHART David, 1838, The Spirit of the East, Henry Colburn, London, vol. 1.

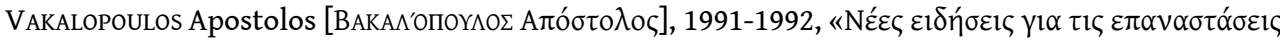

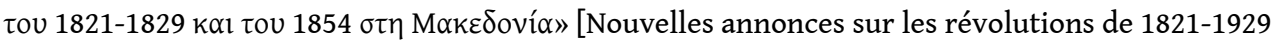

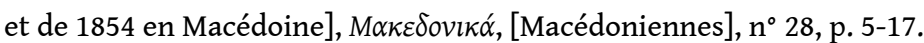

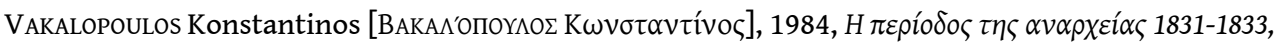

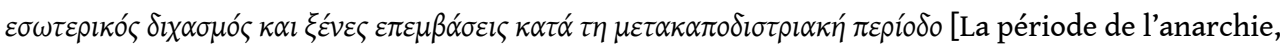
1831-1833, division interne et interventions étrangères pendant la période post capodistrienne],

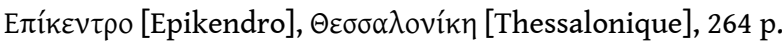

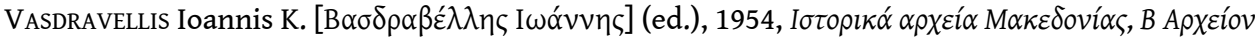

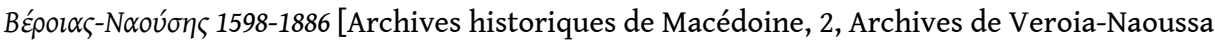

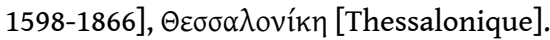




\section{Documents d'archives}

Diplomatic and Historical Archive of the Ministry for Foreign Affairs, Greece (hereafter DHAMA)

Files 1831/65/1.6, 1831/4/1.4, 1832/4/1.7,

General State Archives/Kerkyra Prefecture, Ioannis Kapodistrias Papers (hereafter GSA/KP/ICP)

Files 217, 225, 288, 290, 568

General State Archives/Archive of the General Secretariat (hereafter GSA/AGG),

Files 18, 19, 258b.

MEI

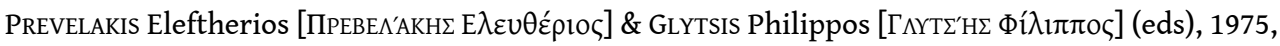

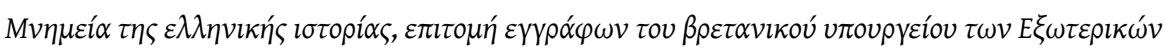
[Monuments de l'histoire grecque, recueil de manuscrits du ministère britannique des Affaires

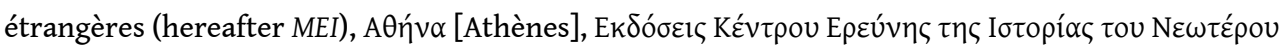

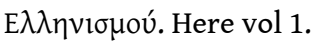

National Archives U.K., Foreign Office (hereafter FO).

Files 78/193, 78/198, 78/203 and 78/216.

Nederlands, Het Archief National (hereafter NL-HaNA.)

Legatie Turkije en de Levant, vol. 138.

\section{NOTES}

1. ANSCOMBE, 2014, p. 77-84.

2. The Greek term "Roumeli", which denoted Sterea Hellas, should not be confused with the Ottoman term "Rumeli", which covered all the European Provinces of the Empire.

3. The reference is (a) to the third London Protocol (March 1829) which set the Amvrakikos-Pagasitikos (gulfs) line as the northern frontier of Greece, and was endorsed by the Porte with the Treaty of Adrianople (September 1829), (b) to the fourth Protocol of London (February 1830) which reduced Greece to the Spercheios-Acheloos (rivers) line, and (c) to the fifth Protocol of London (September 1831) which cancelled the provisions of the fourth protocol. PAPAGEORGIOU, 2005, p. 282-283.

4. KoKKINOS, 1960, vol. 12, p. 140.

5. U RQUHART, 1838, vol.1, p. 178-9, p. 253-5; KOUTSONIKAS, 1863, vol.1, p. 178-9; $\mathrm{A}[$ ravandinos] $\mathrm{P}$ [argeios], 1856, vol. 1, p. 384.

6. PAPAgEORgIOU, 2005, p. 253-5.

7. PHILIMON, 1861, vol. 4, p. 454.

8. KOUTSONIKAS, 1863, vol.2, p. 218 and 220; LEAR, 1851, p. 177-178; MERDJANOVA, 2013, p. 37-41, 149-50.

9. FO 78/193, Meyer to Adam, Preveza, 19 Apr. 1830, f. 95r.

10. KoKKINOS, 1960, vol. 3, p. 299-306, vol. 4, p. 78-91. 
11. Ibid. vol. 3, p. 301-302.

12. ERDEM, 2007, p. 219-22, 224-5.

13. SARRIS, 1993, p. 214-52.

14. ERDEM, 2007, p. 213-40. PHILIMON, 1861, p. 153-66, 285-302. For Kütahı' see URQUHART, 1838, vol. 2, p. 355-360.

15. DONTAS, 1966, p. 17-85.

16. KASOMOULIS, 1970, vol. 3., pp. 97-102. For an overall account see PAPAGEORGIOU, 2005, p. 235.

17. See DonTAS, 1966, p. 169, appendix vii (Meyer to Adam, Preveza, 15 Dec. 1828).

18. For Bushatli, see NEDELJKOVIć, 2015, p. 92-3.

19. DONTAS, 1966, p. 124-125, 169-171, appendix vii; ERDEM, 2007, p. 230-3.

20. ERDEM, 2007, p. 226-9.

21. For Veli Bey Yatzi, see ARAVANDINos, 1856, p. 386 and URQUHART, 1838, vol. 1, p. 179, $184,199$.

22. ERDEM, 2007, p. 232; DONTAS, 1966, p. 108-21; PAPADOPOULOS, 1962, p. 55, 97-118.

23. URQUHART, 1838, vol. 1, p. 179-180; ARAVANDINOS, 1856, p. 378.

24. For the Vliora family see PAPAGEORGIOU, 2014, p. 2-29.

25. DONTAS, 1966, p. 15, 44-5; SPYROMILIOS, 1965, p. 145.

26. ERDEM, 2007, p. 234-7; DONTAS, 1966, p. 172-174.

27. National Archives U.K., Foreign Office (hereafter FO) 78/193, Meyer to Rudsdell, Preveza, 21 Jan., ff. 11r-13v, 27 Jan. 1830, ff. 15r-18v, 1st Feb. 1830, ff. 21r-23v, 14 Feb., ff. 30r-35r, 19 Feb. 1830, ff. 36r-38v and to Aberdeen, 2 Feb., ff. 7r-8r and 20 Feb. 1830, ff. 25r-28r. The Morning Chronicle, 28 May 1829; The Times, 11 Nov. 1829.

28. For the armatole networks, see TzAKIS, 1997, p. 44-69; for a broader presentation, PIZANIAS, 2014, p. 305-335.

29. For capitulation and compromise between the Porte and the Greek chieftains see PAPAGIORGIS, 2003, passim, and TZAKIS, 1997, p. 205-38; PAPADOPOUlOS, 1962, p. 32-40, 69-71, 85; DONTAS, 1966, p. 24-9.

30. DonTAS, 1966, pp. 45-48, 108-121; PAPADOPOUlOS, 1962, p. 97-138.

31. P ReVelakis \& G lytsis (eds), 1975, vol.1a, p. 236 (no 702); Papadopoulos, 1962, p. 149-53; The Morning Chronicle, 28 May 1830.

32. PAPADOPOULOS, 1964, p. 144-69; by the same author, 1986.

33. PAPADOPOUlOS,1962, p. 162; BLADAS, 2014, p. 25-29 ; URQUHART,1838, vol. 1, p. 413-414.

34. VAKALOPOUlOS, 1984, p. 76-7; LouKOS, 1988, p. 48-9, 240-1, 250-1, 279.

35. P APADOPOUlOS, 1962, p. 154-5, 204-7; MEI, vol. 1a, p. 273 (no 800), p. 282-285 (nos 825-831). FO 78/193, Meyer to Adam, Preveza, 29 March, f. 76r-v, 19 Apr., f. 98r, 24 May 1830, f. 113r. General State Archives/Kerkyra Prefecture, Ioannis Kapodistrias Papers (hereafter GSA/KP/ICP), file 225, letters by Rados to Kapodistrias, Missolongi, 12/24 May and 17/29 June 1830; file 288, Pisa to Kapodistrias, Vonitsa, 16/28 May 1830, circular of Mehmed Reşid to the notables of Preveza, Bitola 29 July/10 Aug. 1830; Veli Yatzi to Stathi [Katsikogianni], Preveza, 9/21 and 17/29 March 1830 and to the notables of Vonitsa (s.d.). 
36. GSA/KP/ICP, file 225, Rados to Kapodistrias, Missolonghi, 12/24, 17/29 May, 22 May/3 June, 7/19 June, 1/13 July 1830; file 288, Pisa to Kapodistrias, Vonitsa, 16/28 May and 17/29 June 1830; FO 78/193, Meyer to Aberdeen, Preveza, 1 June, ff. 109r-11r and 8 June 1830, f. 165r; Meyer to Adam, Preveza, 24 May, ff. 113r-114v, 14 June 1830, ff. 160r-161r. Nederlands, Het Archief National (hereafter NL-HaNA.), Legatie Turkije en de Levant, vol.138, Carboneri to de Testa, Thessaloniki, 27 May, no 50 and 25 June 1830, no 52. VASDRAVELLIS (ed.), 1954, p. 304.

37. FO 78/193, Meyer to Adam, Preveza, 8 July, ff. 180r-181v, 17 July, ff. $188 \mathrm{v}-190$ r, 14 Aug., ff. 205r-206r, 19 Aug. 1830, f. 219r-v; to Gordon, Preveza, 9 July, f. 170r-v, 6 Sept. 1830, f. 246v.; to Aberdeen, 26 July, f. 185r-v., 21 Aug. 1830, ff. 196v-200r. FO 78/190, Gordon to Aberdeen, Constantinople, 21 Aug. 1830, f. 232v. GSA/KP/ICP, file 225, Rados to Kapodistrias, Missolonghi, 4/16 and 12/24 Aug. 1830; file 288, Pisa to Kapodistrias, Vonitsa, 17/29 June 1830; David URQUHARt, op. cit., vol. 1, pp. 190-2, 247-63, 308-12; FanshaWe Tozer, 1869, vol.1, p. 167-9. The Times, 17 Sept. 1830; A RaVAndinos, 1836, p. 387-388.

38. FO 78/193, Meyer to Adam, Preveza, 14 Aug., f. 208r, 16 Aug., f. 213r. 28 Aug. 1830, f. 219r-v. GSA/KP/ICP, file 225, Rados to Kapodistrias, Missolonghi, 22 Aug./3 Sept., 26 Aug./7 Sept., 30 Aug./11 Sept. 1830; file 217, 17/29 Sept., 3/15 Nov., 1/13 Dec. 1830; file 290, Kapodistrias to Zéénelie and Loulé, Nafplio, 18/30 Oct. 1830.

39. GSA/KP/ICP, file 217, Rados to Kapodistrias, Missolonghi, 12/24 Aug. and 17/29 Sept. 1830; FO 78/193, Meyer to Aberdeen, Preveza, 24 Sept. 1830, f. 262r-v.; to Adam, Preveza, 14 Aug., ff. 209v-10r, 11 Nov. 1830, f. 297 r.

40. FO 78/193, Meyer to Aberdeen, Preveza, 24 Sept. 1830, f. 262v; to Adam, 26 Sept., f. 290r, 22 Oct., f. 282r-v, 11 Nov. 1830, ff. 299r-300r. NL-HaNA., Legatie Turkije en de Levant, vol. 138, Carboneri to de Testa, Thessaloniki, 13 Oct., no 60 and 27 Oct. 1830, no 62. GSA/KP/ICP, file 217, Rados to Kapodistrias, Missolonghi, 6/18 Oct. and 3/15 Nov. 1830.

41. A RAVANDINOS, 1836, p. 388-9. GSA/KP/ICP, file 225 , Rados to Kapodistrias, Missolonghi, 26 Aug./7 Sept. 1830; file 217, 4/16 Oct., 9/21 Nov. 1830; FO 78/193, Meyer to Aberdeen, Preveza, 22 Dec. ¿1830, ff. 303v-309r. For Mehmed Reşid's dispach to the pastoralists see General State Archives/Archive of the General Secretariat (hereafter GSA/AGG), file 258b, Ioannina, 30 Dec. 1830/11 Jan. 1831.

42. FO 78/193, Meyer to Adam, Preveza, 14 Aug. 1830, ff. 209v-210r, 11 Nov. 1830, f. 297r. GSA/KP/ICP, file 225, Rados to Kapodistrias, Missolonghi, 12/24 Aug., 22 Aug./ 3 Sept., 26 Aug./7 Sept. 1830; file 217, 17/29 Sept., 3/15 Nov., 1/13 Dec. 1830.

43. MEI, vol. 1a, pp. 215 (no 646), 295-302 (nos 867-78), 318-9 (no 920), p. 337 (no 978), p. 339-40 (nos 987-8, 990), p. 347 (no 1007), p. 349 (no 1012), p. 364 (no 1058), p. 365 (no 1060). GSA/KP/ICP, file 217, Rados to Kapodistrias, Missolonghi, 10/22 Sept. 1830. FO 78/193, Meyer to Aberdeen, Preveza, 24 Sept. 1830, f. 263r-v and Mehmed Reşid to Meyer, Bitola, 13/26 Sept. 1830, ff. 277r-278v.

44. FO 78/193, Meyer to Aberdeen, Preveza, 22 Dec. 1830, f. 303r.

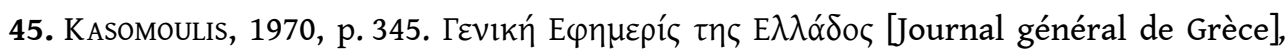
3/15 and 10/22 Jan. 1831. VaKalopoulos, 1991-1992, p. 5-9, 13-17. Diplomatic and Historical Archive of the Ministry for Foreign Affairs, Greece (hereafter DHAMA), file. 1831/65/1.6, Moustoxydis to Kapodistrias, Thessaloniki, 16/28 Dec. 1830; Milaitis to Government Secretary, Skopelos, 28 Jan./9 Feb. 1831, no 169; Dimandis to Kapodistrias, 
Nafplio, 27 June/9 July 1831. NL-HaNA., Legatie Turkije en de Levant, vol. 138, Carboneri to de Testa, Thessaloniki, 31 Dec. 1830, no 67; vol. 285, 25 Jan., no 68, 10 Feb., no. 69, 28 Feb., no 70, 25 March 1831, no 72. MEI, vol.1a, p. 464 ( $\alpha \rho . \varepsilon \gamma \gamma \rho .1363$ ). FO 78/203, Meyer to Rudsdell, Preveza, 2 Jan. 1831, f. 16v.; to Palmerston, 24 Jan. 1831, f. 46r.

46. FO 78/198, Gordon to Palmerston, Constantinople, 26 Feb. 1831, ff. 93r-103r. Kapodistrias's reply is also available at DHAMA, file 1831/4/1.4, Nafplio, 5/17 Jan. 1831.

47. FO 78/198, Résumé d'une lettre adressée par le Grand Vizir aux Consuls de France et de Russie, février 1831, ff. 148r-150v.

48. MEI, vol. 1a, pp. 215-6 (no 647).

49. GSA/KP/ICP, file 217, Rados to Kapodistrias, Missolonghi, 27 Dec. 1830/8 Jan. 1831, 9/21 Jan., 12/24, 15/27, 18/30, 21 Jan./2 Feb., 26 Jan./7 Feb. 1831. FO 78/203, Meyer to Adam, Preveza, 30 Jan. 1831, f. 57r; Meyer to Palmerston, Preveza, 9 Feb. 1831, ff. $51 \mathrm{r}-52 \mathrm{r}$.

50. GSA/KP/ICP, file 217, Rados to Kapodistrias, Missolonghi, 27 Dec. 1830/8 Jan., 9/21 Jan., 30 March/11 Apr., 23 Apr./5 May, 28 Apr./10 May, 5/17 May, 29 May/10 June, 5/17 June 1831; Pappastathopoulos to Rodos, Vonitsa, 23 May/4 June 1831; General State Archives/The Archive of the Governor Plenipotentiary (hereafter GSA/AGP), file 18, Rados to A. Kapodistrias, Missolonghi, 15/27 March, 2/14 May, 7/19 May 1831; Kastanas to A. Kapodistrias, Karvasaras, $27 \mathrm{March} / 8 \mathrm{Apr} .1831$, Ligovisti, 15/27 Apr. 1831, Vonitsa, 30 Apr./12 May, 13/25 May 1831; Yannakis Yoldasis to A. Kapodistrias, Karpenisi 23 May/4 June 1831; Tzanoglou to A. Kapodistrias, Karpenisi, 23 May/4 June 1831, Rangos to Tzatzios, Chamoryanni, 4/16 June 1831; DHAMA, file 1831/4/1.4, Rados to Kapodistrias, Missolonghi, 29 May/10 June 1831. KAsomoulis, 1970, p. 366-82; SPILIADIS, 2007, vol. 4, p. 525; PAPAGEORGIOU, 1985, p. 33.

51. NACI, 1986, p. 171-173, 177, 183.

52. FO 78/203, Meyer to Palmerston, Preveza, 9 Feb., f. 52r, 24 June 1831, f. 164v; Meyer to Adam, Preveza, 23 Apr., f. 119v., 26 Apr. 1831, f. 122r-v; Emin to Meyer, Ioannina, 12/24 Apr., f. 126r-v., 5 May 1831, f. 141r-v. NL-HaNA., Legatie Turkije en de Levant, vol. 285, Carboneri to de Testa, Thessaloniki, 8 May 1831, no. 80 and 9 May 1831, no 81. Nedeljković, 2015, p. 97-98.

53. FO 78/203, Meyer to Palmerston, Preveza, 25 May 1831, f. 147r-v; GSA/AGP, file 18,

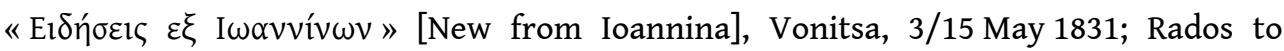
A. Kapodistrias, 18/30 May 1831; Pappastathopoulos to A. Kapodistrias, Vonitsa, 23 May/4 June 1831; Yannakis Yoldagis to A. Kapodistrias, Karpenisi, 23 May/ 4 June 1831. GSA/KP/ICP, file 217, Rados to Kapodistrias, Anatoliko, 9/21 May 1831 and Missolonghi, 23 May/4 June 1831; Velis to Rados, Langada, 21 May/2 June 1831.

54. GSA/KP/ICP, file 217, Rados to Kapodistrias, Missolonghi, 27 Dec. 1830/8 Jan. 1831, 9/21, 12/24, 15/27, 18/30 Jan., 2, 7 Feb. 1831. FO 78/203, Meyer to Adam, Preveza, 30 Jan. 1831, f. 57r; to Palmerston, Preveza, 9 Feb. 1831, ff. 51r-52r.

55. DHAMA, file 1831/4/1.4, Emin to Kapodistrias, Ioannina, 15/27 Apr. 1831.

56. All the correspondence is available at DHAMA, file 1831/4/1.4. See also MEI, vol. 1a, p. 485 (no 1412) and pp. 486-7 (nos 1415-6). FO 32/21, Dawkins to Palmerston, Nafplio, 19 June 1831, ff. 139r-141r.

57. DHAMA file 1831/4/1.4, Kapodistrias to Karapavlos, Nafplio, 4/16 June 1831. 
58. GSA/KP/ICP, file 217, Rados to Kapodistrias, Missolonghi, $13 / 25$ June 1831. For the detailed reports submitted by to Palmerston, Rudsdell and Dawkins, and all the attachments see: FO 78/203, Meyer to Palmerston, Ioannina, 10 July 1831, ff. 172r-174r and 25 Aug. 1831, ff. 184r-188r; to Rudsdell, Ioannina, 9 July 1831, ff. $180 \mathrm{r}-182 \mathrm{v}$; to Dawkins, Ioannina 22 Aug. 1831, ff. 190r-220r. See also the reports by Karapavlos to Kapodistrias, Ioannina, 27 June/9 July 1831 and Nafplio, 29 Aug./10 Sept. 1831) at DHAMA file 1831/4/1.4.

59. DHAMA/1831/4/1.4, Kapodistrias to Mehmed Reşid, Nafplio, 22 Sept./4 Oct. 1831, no 864; Kapodistrias to the vice-ambassadors, Nafplio, 22 Sept./4 Oct. 1831, no 865; Kapodistrias to Rückmann, Nafplio, 22 Sept./4 Oct. 1831, no 867; Kapodistrias to the commissioners of Eastern and Western Greece, Nafplio, 21 Sept./3 Oct. 1831, no 866.

60. FO 78/203, Meyer to Palmerston, Ioannina, 25 Aug. $1831 \mathrm{ff} .186 \mathrm{v}-187 \mathrm{v}$ and Arta, 20 Oct. 1831, ff. 235r-236v. GSA/AGP, file 19, Rados to A. Kapodistrias, Missolonghi, $1 / 13$ Sept. 1831.

61. Sel TURHAN, 2014, p. 66-9; Aličıč, 1996, p. 305-12; Kamberović, 2002, p. 50-61; Pollo, 1984, p. 118-26; THËNGJILLI, 1981.

62. GSA/KP/ICP, file 568, Rados to A. Kapodistrias, Missolonghi, 20 Oct./1 Nov. 1831; PAPAGEORgiou (ed.), 1992, p. 647-8 (no 686) and p. 630 (no 665); KASOMOULIS, 1970, p. 487. PAPAGEORGiou, 2005, p. 291-3; FO 78/216, Meyer to Palmerston, Preveza, 21 Jan. 1832,

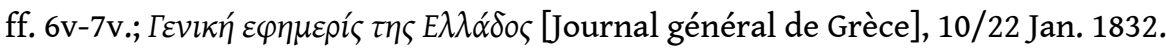

63. DHAMA, file 1832/4/1.7, Mehmed Reşid to Koundouriotis, Ypsilantis, Zaimis, camp in Syria, 13/25 July 1832.

64. $\Sigma \omega \tau \eta ́ p$ [Sauveur], 19/31 May 1835, p. 90.

\section{ABSTRACTS}

In the last stage of the disastrous war for Greek independence (1829-31), the suggested northern frontier line changed three times. The uncertain future of the region, the pressure of the central government to create regular armed forces and to safeguard security along the new border land brought the local Greek and Albanian military élites, after ten years of heavy fighting, in an awkward position. Their options were restricted and their welfare as mercenaries was threatened. The crumbling Empire and the soon-to-be Greek nation-state, were unpredictable in their responses either as allies or as enemies. Their choices of reaction varied, yet their method was uniform: to bargain tough before compromising, even if the given choice involved mutiny and extensive civil strife. Their opponents, on the other side, Governor Ioannis Kapodistrias and Grand Vizier Mehmed Reşid had to show in the eyes of the Great Powers determination and improvisation, in order to gain the necessary prestige and win back the disputed territories. Eventually the making of the frontier forced both warlords and politicians to transform their tactics and reconsider their alliances.

Dans les dernières années de la catastrophique guerre d'indépendance grecque (1829-1831), la frontière nord de la Grèce qui fut suggérée, changea trois fois. Le futur incertain de la région, les 
pressions du gouvernement central en vue de créer une armée régulière et d'assurer la sécurité dans les nouvelles régions frontalières mirent les élites grecques et albanaises dans une position difficile, après dix ans de durs combats. Leurs options étaient réduites et leur prospérité, comme mercenaires, menacée. Les réactions, que ce soit comme alliés ou comme ennemis, de l'Empire ottoman déclinant et de l'État grec en construction étaient imprévisibles. Il y avait diverses réactions possibles mais leur choix fut le même: négocier sévèrement leur place avant de se soumettre, même si cela supposait une révolte et des luttes civiles. De l'autre côté, leurs adversaires, le gouverneur Ioannis Capodistria et le Grand vizir Mehmed Reşid devaient montrer aux grandes puissances à la fois leur volonté et leur capacité d'improvisation, pour conserver leur prestige et retrouver les territoires qu'ils risquaient de perdre. Le tracé d'une frontière contraignit finalement autant les combattants que les politiques à changer leur tactique et à revoir leurs alliances.

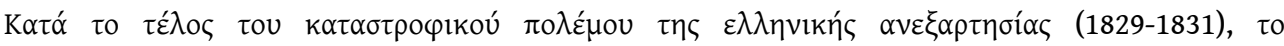

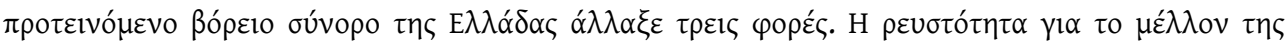

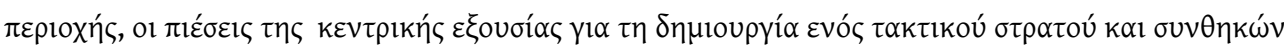

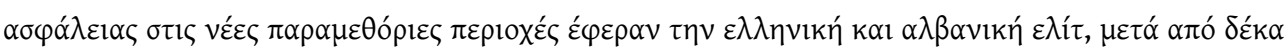

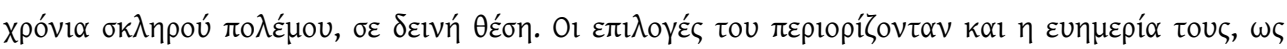

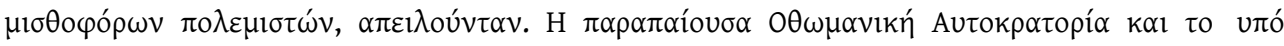

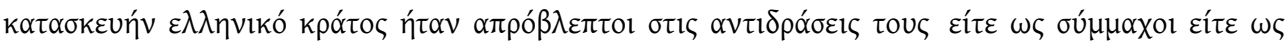

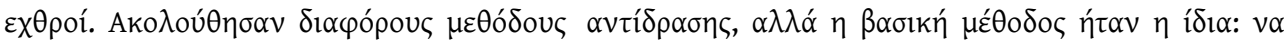

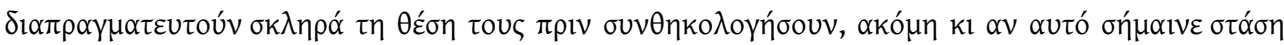

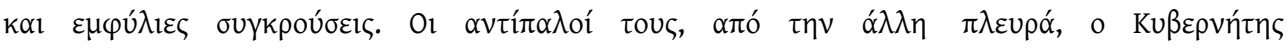

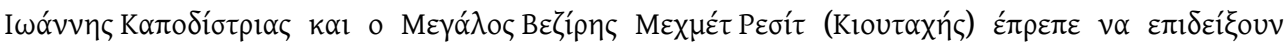

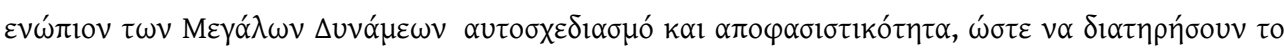

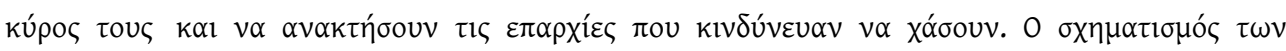

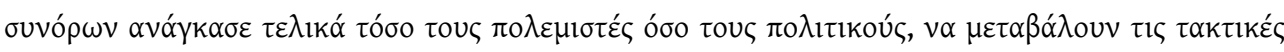

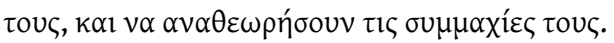

\section{INDEX}

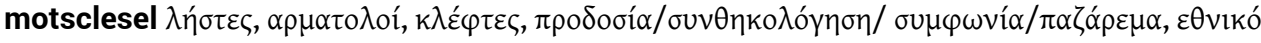

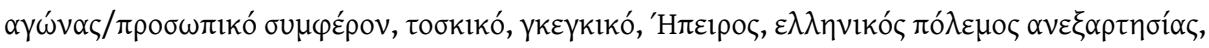

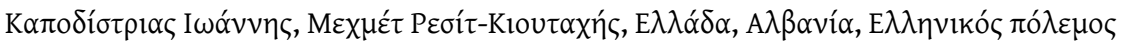

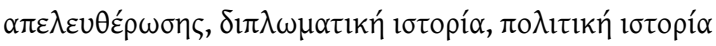

Mots-clés: brigands, brigands, armatoles, armatoles, klephtes, klephtes, trahison/soumission/ accord/marchandage, trahison/soumission/accord/marchandage, cause nationale/intérêt personnel, cause nationale/intérêt personnel, tosque, tosque, guègue, guègue, Épire, Épire, guerre d'indépendance grecque, guerre d'indépendance grecque, Kapodistrias Ioannis, Kapodistrias Ioannis, Mehmet Rechid-Kioutachis., Mehmet Rechid-Kioutachis.

motsclestr haivutlar, armatol, klepht, ihanet/kapitülasyon anlaşma/pazarlık, ulusal neden/ kişisel ilgi, tosk, geg, Epirus, Yunan Kurtuluş Savaşı, Kapodistrias Yannis, Reşid Mehmed, Yunanistan, Arnavutluk, Yunan bağımsızlık savaşı, siyasi tarih, diplomasi tarihi

Keywords: robbers, armatols, klephts, betrayal/capitulation/agreement/haggling, national cause/personal interest, tosk, gegh, Epiros, Greek independence war, Kapodistrias Ioannis, Reşid Mehmed-Kütahı, Greece, Albania, Greek war of independence, political history, diplomatic history 
AUTHOR

BASIL C. GOUNARIS

Aristotle University of Thessaloniki 